\title{
Occupation and Bladder Tumor: Result of the incident cases
}

\author{
M M TAHIR K HAYAT K H BHATTI S HUSAIN \\ 1) prartment of ( rolog), Allama lqbal Medical (ollege Jimnah Hospital Lahore \\ (orrespondence lo i)r: Muhammad Muzammil Tahir
}

\begin{abstract}
Bladder tumour is a devastating condition demand a lot of consultation and follow up. In patients suffering from superficial bladder tumour recurrence rate after five years follow up is $15-20 \%$. The occupation most commonly concerned with bladder tumour are farmers, persons dealing with pesticide, dye industry, transport and office workers. We conducted the study to see the occupational involvement in our set up. We found the farmers $43.2 \%$ are most commonly involved in bladder tumour. The uncontrolled use of pesticides, illiteracy, poor economic condition and non-availability of basic diagnostic tool at gross root level are the main cause in its late diagnosis and treatment.
\end{abstract}

Key words: Bladder tumour, occupation, farmers

Bladder Tumor is second most urological malignancy. In united states of America, nearly 12,000/year deaths are recorded due to this devastating disease. Nearly 7000 new cases are recorded due to this. ${ }^{1}$ in Britain. Alone. While in United states of America, this figure arose to 49,000/year. ${ }^{2}$ In occupational groups, farmer's stand 1st, with industrial workers place second in long queue. ${ }^{3}$ Strong incidence of increased is apparent for very few occupations, dye workers, aromatic amines manufacturing workers, leather workers, rubber workers, painter, truck driver, and aluminum workers. The vast majority nearly $90 \%$, are Transitional cell carcinoma, remainder are typed either as Squamous cell carcinoma or adenocarcinoma.

Painless hematuria is the main presenting symptom of bladder cancer, with irritative symptom contributing in few patients. Patient with this symptom require a cystoscopy and imaging of the upper tract either by means of intravenous urography (IVU) or plain abdominal radiography with ultrasonography. Urine cytology should also be assessed .TUR (BT) is the mainstay of treatment. At the time of initial resection, the patient should be assessed clinically, bimanually, and tumor is resected or biopsy is taken to assess the grades of the tumor.

We have conducted this study to assess the involvement of different occupational group in this disease. As Pakistan is basically agricultural country, with sporadic industrial setup, we noticed increased incidence in last few years, and mostly patients belongs to rural area.

\footnotetext{
Material and Method

We have selected the patients that are presented in the Urology department of Jinnah Hospital Lahore, both as an out door and in the emergency for their complaints. During the period from 1995 to 2000 , we collected 97 patients, in a row, and there data was collected to assess the type of occupation and there involvement in bladder tumor. We divided the occupation, in farmers, industrial workers, office workers, House wives, others, which does not fall in any above mentioned category
}

\section{Results}

Out of total 97 patients, 84 persons were male, while 13 female contributed the rest. Out of total 97 patients, 42 were farmer, 18 were industrial worker, and 37 people belong to other services group.

Table-1: Occupational involvement

\begin{tabular}{lll}
\hline Farmer & Industrial worker & Services group \\
\hline $42(43.2 \%)$ & $18(18.5 \%)$ & $37(38.5 \%)$ \\
\hline
\end{tabular}

Among the services group, $38.5 \%$ were house wives, $5.15 \%$ were office worker, while $17.5 \%$ belongs to other services, like school teacher, jobless, etc

\section{Discussion}

Bladder tumor is devastating disease affecting the diverse group of occupations. There is nearly 40 high risk occupations, despite prodigious efforts, epidemiologist remain uncertain of the exact level of risk involved. Typically a small number of workers are studied and their risk of bladder cancer is less than twice than expected. Strong evidence of increased risk is apparent for very few orcupations: dye worker, aromatic manufacturing workers, leather workers, rubber worker, painter, truck driver, and aromatic worker ${ }^{2}$. This view is also supported by Zheng et all, that many reported association are not consistent, and strong evidence of increased risk is apparent for few occupational groups. They concluded that increased risk is observed for industries, plumbing, heating, air conditioning, rubber and plastic products, motor vehicle parts, and occupational involving the transportation and material moving., auto mobile machines, and plastic working machines operator, while in women significant no of the patient belongs to teachers, housekeeper, and workers in laundry, and dry cleaning industry ${ }^{10}$. Substances that are notorious for the production of bladder tumor are exposure to benzidine, aromatic amines, and beta nephthalamine, used typically in the dye and rubber industries, is associated with a thirty fold increased risk of transitional cell carcinoma ${ }^{7}$. We have studied the cases 
who reach the hospital. In our study the majority $43.2 \%$ were farmer, while industrial worker comprises $18.5 \%$, and other services comprises $38.5 \%$. Our study is near to, with few differences, to Spanish study, where farmer comprises. $33.18 \%, 15.6 \%$ belong to industrial sector, while $51.20 \%$ are in the services sector

3.6. The increased risk of bladder cancer in Printing and textile industry, as was reported in previous studies, in now a day nullified by Rafnsson V, and Serra $C$ et all, respectively, who in a controlled study nullify this evidence ${ }^{+5}$.

The increase incidence in farmers is due to more population involved in agricultural sector. While this is also related to increase use of Pesticides, containing benzedine group, and their uncontrolled use with out adopting safeguard measures. The associations of the symptoms, to prostatic enlargement, which usually present in old age, very much mimic the symptoms of the bladder tumor contribute a lot in late presentation in the hospital, as the mean age of presentation in Pakistan for bladder tumor, is $7^{\text {th }}$ decade of life ${ }^{8.9}$. . Other factor responsible for delay in presentation, are illiteracy, poor socioeconomic status of the people ${ }^{11}$. and non availability of basic diagnostic facility at rural health centre, tehsil head quarter, even at district health quarter level..

\section{Conclusion}

Bladder tumor presentation in Pakistan, is at its peak in the seventh decade of life. It is a disease, that have good prognosis, if detected earlier and treated earlier. The use of mass media, for creating awareness among the general public regarding hazards of excessive use of pesticide and proper adoption of safeguard when pesticides are used for spray. Encouraging the people to use the organic vegetables, grains and fruits. The provision of ultrasound facility at rural health centre level, and provision of the endoscopic instrument at least at the tehsil head quarter level, helps a lot in early detection of tumor and its proper management. In the industrial sector there should be regular check up of all the personals involved, particularly those, that work in industry, notorious for high risk for bladder tumor.

\section{References}

1. Griffith TRL, Neal DE. Management of superficial Bladder Cancer. Recent advances in surgery. 1999: 77-91

2. Silverman DT, Hartage $P$ et al. Hematology/Oncology Clinics of North America: 1992: (1): 1.

3. Fernandiz A, Gil Fabra J, Vazquez, Medrano A, Otero MG: Occupation and Bladder tumor. Result of study of Incident Cases: Actas-Urol-Esp.1995: 19(2): 128-30.

4. Rafnsson V. Incidence of Cancer among Bookbinders, Printers, Photoengravers, and typesetters.Occup Environ Med. 2001.58(8):523-7.

5. Serra C, Bonfill X, Sunyer J, Urrutia G, Turuguet D, Bastus R, Roque M. T Mannetje A, Kogevinas M: Bladder Cancer in the Textile Industry. Scand J Work Environ Health 2000: 26(6): 476-81.

6. Fernandez A, Gil Fabre J, Fernandez RM. Superficial and infiltrating bladder tumor. Epidemiologic differences in a study of incident cases; Actas Urol Esp: 1994: 18(10): 983.

7. Philip J, Kumar V, Bruden G: Bladder Cancer: Urology, The medical publishing company Ltd. 2002.281-284.

8. Sial AR, Sheikh SM, Jalbani MH, Rathi SL, Chand H. A clinco pathological Study of 108 cases of urinary bladder cancer at Chandka medical college \& hospital Larkana; J Surg Pak(int);1999; 4(1). 7-9.

9. Tahir MM, Iqbal M, Husain S, Nawaz A, Ahamed M, Ahmed Naeem; Recurrence on $1^{\text {st }}$ check cystoscopy in patients with superficial bladder tumor after TUR(BT): Annals of KE; 2000;6(3);258-260.

10. Zhang T, Cantor KP, Zhang Y, Lynch CF; Occupation and Bladder Cancer; a population based case controlled study in Iowa; J Occup Environ Med; 2002;44(7):685-91

11. Aziz Z, Sana S; Cancer treatment in Pakistan; Challenges and obstacles: Gan To Kagaku Ryoho; 2002Feb;29 Supple 1:4-8. 